\title{
MENOLAK POLITIK UANG \\ (TINJAUAN UU NO. 7 TAHUN 2017 DAN AJARAN GEREJA)
}

Oleh: Ignasius Suswakara

\begin{abstract}
Abstrak:
Pemillihan umum (Pemilu) di Indonesia tanpa politik uang mungkin aneh bagi masyarakat saat ini. Praktik politik uang yang selalu terjadi dalam setiap pemilu membuat masyarakat berpikir dan merasa bahwa praktik ini merupakan hal yang lumrah. Masyarakat seperti dibawa kepada pemahaman bahwa pemberian uang untuk memilih calon tertentu adalah suatu kewajiban dari peserta pemilu kepada pemilih. Praktik politik uang yang terjadi secara terus menerus, benar-benar menggerus moralitas umat beragama, terutama agama Katolik. Praktik politik uang yang menahun ini menimbulkan pertanyaan: apakah ajaran Gereja memang tidak melarang politik uang? Ataukah umat yang tidak menyadari bahaya politik uang sekalipun dilarang oleh Gereja? Tulisan ini mengangkat persoalan politik uang dalam UU No. 7 Tahun 2017 dan ajaran Gereja Katolik terhadap masalah kronis ini.
\end{abstract}

Kata-kata Kunci: Politik Uang, Pemilu, Gereja, Kebaikan Umum.

\section{Praktik Politik Uang}

$O^{2}$ ejak awal, salah satu pertimbangan peralihan mekanisme pilkada oleh DPRD menjadi pilkada langsung adalah untuk memangkas politik uang (money politics), logikanya calon tidak punya kemampuan untuk membeli suara rakyat yang jumlahnya banyak. Namun fakta menunjukkan bahwa dalam pilkada langsung pun politik uang berlangsung meski dengan ongkos yang makin mahal karena melibatkan pemilih dalam satu daerah pemilihan. Regulasi yang lemah sejak awal, memungkinkan praktik politik uang telah mewabah dan sulit dihilangkan. Sulit dihilangkan karena politik uang yang telah dilakukan sejak awal pencalonan akan terus berlanjut hingga sang kandidat menjabat, mencalonkan diri lagi, dan ketika ia tidak dapat mencalonkan diri, maka ia akan mencalonkan orang lain yang mendukungnya. Inilah rantai politik uang yang tidak habis-habisnya jika tidak segera diatasi.

Politik uang yang menjamur bahkan dapat menjadi tolak ukur dari masyarakat untuk mengukur peserta pemilu dari sisi finansial. Jika peserta pemilu memberikan sejumlah uang yang banyak maka dianggap mampu menjadi seorang anggota legislatif atau kepala daerah. Sebaliknya, jika jumlah uang diberikan sedikit dianggap calon tersebut belum mampu. Kebutuhan masyarakat akan uang tunai menjadi pemicu makin maraknya praktik ini di tengah masyarakat. Dengan beragam dalih, peserta pemilu dapat menghalalkan politik uang untuk memenangkan pemilu.

Secara umum, politik uang (money politic) diartikan sebagai upaya yang dilakukan seseorang dengan tujuan untuk mempengaruhi orang lain dengan menggunakan imbalan tertentu. Imbalan tersebut dapat berbentuk uang maupun barang tertentu. ${ }^{1}$ Pendapat yang sama dikemukakan oleh Yusril Ihza Mahendra sebagaimana dikutip oleh Indra Ismawan menyatakan bahwa money politic dilakukan dengan tujuan untuk mempengaruhi massa

${ }^{1}$ Sri Wahyu Ananingsih, Tantangan Dalam Penanganan Dugaan Praktik Politik Uang Pada Pilkada Serentak 2017, Jurnal Masalah-masalah Hukum, Vol 45, No 1 (2016). Diunduh dalam ejournal.undip.ac.id/index.php/mmh/article/view/13671, tanggal 11 Nopember 2018. 
pemilu dengan imbalan materi. ${ }^{2}$ Menurut Wahyudi Kumorotomo (2009) ada beragam cara untuk melakukan politik uang dalam pilkada langsung, yakni: (1) Politik uang secara langsung bisa berbentuk pembayaran tunai dari "tim sukses" calon tertentu kepada konstituen yang potensial, (2) sumbangan dari para bakal calon kepada parpol yang telah mendukungnya, atau (3) "sumbangan wajib" yang disyaratkan oleh suatu parpol kepada para kader partai atau bakal calon yang ingin mencalonkan diri sebagai bupati atau walikota. ${ }^{3}$ Adapun politik uang secara tidak langsung bisa berbentuk pembagian hadiah atau sumbangan, pembagian sembako kepada konstituen, pembagian semen di daerah pemilihan tertentu, dan sebagainya. Para calon bahkan tidak bisa menghitung secara persis berapa yang mereka telah habiskan untuk sumbangan, hadiah, spanduk, dan sebagainya, disamping biaya resmi untuk pendaftaran keanggotaan, membayar saksi, dan kebutuhan administratif lainnya.

Mata rantai politik uang ini membuktikan bahwa sistem politik sekarang ternyata tidak cukup untuk menjamin tidak terjadinya politik uang. Biaya politik yang besar bagi peserta pemilu membuat mereka harus mengeluarkan banyak biaya untuk maju menjadi peserta pemilu. Dilansir oleh Kompas.com menyatakan bahwa untuk menjadi seorang calon anggota DPR RI, seseorang dapat mengeluarkan uang sebesar Rp 1 miliar s.d. Rp. 2 miliar. Berikutnya: untuk menjadi calon anggota DPRD Provinsi, sebesar Rp 500 juta s.d. Rp 1 miliar, calon anggota DPRD kabupaten/kota, sebesar Rp 250 juta s.d. Rp 300 juta. ${ }^{4}$ Biaya ini harus disetor ke pengurus partai untuk menyetujui pencalonan mereka. Logikanya mereka yang berhutang untuk biaya pilkada, akan membalas jasa melalui berbagai konsensi kepada pihak yang mengongkosinya pascapilkada, dan pada akhirnya meminggirkan aspirasi masyarakat luas. Situasi ini pula yang belakangan melahirkan perilaku korup para kepala daerah guna mengembalikan hutang-hutang semasa pilkada, karena seperti pendapat Eko Prasojo, bahwa biaya yang dikeluarkan ini (menentukan parpol pengusung, kampanye besarbesaran untuk mendongkrak popularitas calon, sampai upaya mempengaruhi pilihan masyarakat) harus diganti oleh uang rakyat dalam APBD melalui arisan proyek bagi investor politik yang ikut membiayai pilkada. ${ }^{5}$ Selain secara finansial merugikan masyarakat daerah dengan korupsi APBD, praktik politik uang juga mencendarai terwujudnya pemilu yang demokratis. Suatu pemilu yang demokratis, jujur dan adil (free and fair elections) adalah pemilu yang bebas dari kekerasan, penyuapan, dan berbagai praktik curang lainnya yang akan mempengaruhi hasil pemilu.

Biaya yang besar untuk menjadi peserta pemilu, bukanlah akhir dari permainan politik. Peserta pemilu harus berhadapan dengan masyarakat pemilih yang suaranya mereka butuhkan. Di sini, politik uang merupakan bagian dari upaya para politisi untuk meraup suara. Sekalipun, mereka mengetahui bahwa politik uang tidak menjadi jaminan bahwa suara masyarakat memilih mereka. Namun, dengan adanya jaminan dari "calo-calo politik uang", para peserta pemilu merasa yakin bahwa mereka dapat meraup suara dari masyarakat dimana mereka telah memberikan sejumlah uang.

Fenomena "calo-calo politik uang" ini memang telah banyak berkembang seiring dengan banyaknya pemilu yang melibatkan masyarakat. Dimulai dari Pilkada (Pemilihan

${ }^{2}$ Indra Ismawan, Money Politics Pengaruh Uang dalam Politik (Yogyakarta: Media Presindo, 1999), hal. 4.

${ }^{3}$ Kumorotomo, Wahyudi, "Intervensi Parpol, Politik Uang Dan Korupsi: Tantangan Kebijakan Publik Setelah Pilkada Langsung”, Makalah, disajikan dalam Konferensi Administrasi Negara, Surabaya, 15 Mei 2009. Dikutip oleh Fitriyah, Fenomena Politik Uang dalam Pilkada, Politika Jurnal Ilmu Politik. Diunduh dalam. https: //ejournal.undip.ac.id/index.php/politika/article/view/ 4824/4373, tanggal 16 Nopember 2018.

${ }^{4}$ Https://ekonomi.kompas.com/read/2018/08/01/064607526/ingin-jadi-calegberapa-miliar-danadibutuhkan, diakses tanggal 16 Nopember 2018.

${ }^{5} \mathrm{Https} / / /$ ditpolkom.bappenas.go.id/.../007. pdf, diakses tanggal 11 Nopember 2018. 
Kepala Daerah), Pilgub (pemilihan gubernur), Pileg (Pemilihan Anggota Legislatif) hingga Pilpres (Pemilihan Presiden dan wakilnya). Partisipasi masyarakat bagi para politisi merupakan suatu tantangan karena tidak semua warga masyarakat mau dan aktif dalam mengikuti proses pemilu. Rendahnya kesadaran masyarakat untuk berpartisipasi dalam pemilu menjadikan mereka sasaran empuk para politisi. Politik uang menjadi suatu keniscayaan. Hadirnya "calo-calo politik uang" menjadi penghubung antara masyarakat dan para politisi. Dengan iming-iming dukungan dari masyarakat, "calo-calo politik uang" membuat semacam kontrak atau perjanjian dengan peserta pemilu. "Calo-calo politik uang" bisa siapa saja, yang dianggap mempunyai pengaruh di tengah masyarakat. Mereka bisa saja menawarkan diri atau malah dicari oleh para peserta pemilu.

Sayangnya, dari masyarakat pemilih malah tidak mempunyai prinsip yang jelas untuk menangkal politik uang. Pengaruh agama dan adat tidak cukup untuk mengatasi pengaruh politik uang. Padahal, sudah banyak pemuka agama dan tokoh masyarakat yang telah mengingatkan umat tentang bahaya politik uang. Kebutuhan hidup menjadi alasan bagi masyarakat untuk tetap menerima sejumlah uang dari peserta pemilu, sekalipun hal itu diketahui sebagai sesuatu yang salah. Masyarakat tidak melihat adanya kaitan antara menerima sejumlah uang dari peserta pemilu dengan kebebasan memilih. Bagi mereka, politik uang tidak menggerus kebebasan politik mereka. Sekalipun, dalam kenyataan hal itu cukup mempengaruhi mereka dalam memilih calon tertentu.

\section{Larangan Politik Uang dalam UU No. 7 Tahun 2017}

Pada tahun 2017, DPR bersama Presiden telah menetapkan UU no 2017 tentang pemilihan umum. Dalam UU No. 7 Tahun 2017 tentang pemilihan umum dikatakan bahwa Pemilihan Umum yang selanjutnya disebut pemilu adalah sarana kedaulatan rakyat untuk memilih anggota Dewan Perwakilan Rakyat, anggota Dewan Perwakilan Daerah, Presiden dan Wakil presiden, dan untuk memilih anggota Dewan Perwakilan Rakyat Daerah, yang dilaksanakan secara langsung, umum, bebas, rahasia, jujur, dan adil dalam Negara Kesatuan Republik Indonesia berdasarkan pancasila dan Undang-Undang Dasar Negara Republik Indonesia Tahun 1945. Asas bebas dan jujur merupakan bagian dari pemilu yang menjadikan politik uang menjadi sesuatu yang dilarang. Hal ini diatur dalam Pasal 228, 242, 280, yang mengatur pelarangan bagi partai politik, pelaksana, peserta, dan tim kampanye pemilu untuk melakukan politik uang berupa menjanjikan atau memberikan uang atau materi lainnya kepada pemilih.

Dalam Pasal 228, ayat 1 dan 2 tertulis: (1) Partai Politik dilarang menerima imbalan dalam bentuk apa pun pada proses pencalonan Presiden dan Wakil Presiden. (2) Dalam hal Partai Politik terbukti menerima imbalan sebagaimana dimaksud pada ayat (1), Partai Politik yang bersangkutan dilarang mengajukan calon pada periode berikutnya. Dalam Pasal 280 ayat 1 tertulis: (1) Pelaksana, peserta, dan tim Kampanye Pemilu dilarang: a. mempersoalkan dasar negara Pancasila, pembukaan Undang-Undang Dasar Negara Republik Indonesia, Tahun 1945, dan bentuk Negara Kesatuan Republik Indonesia; b. melakukan kegiatan yang membahayakan keutuhan Negara Kesatuan Republik Indonesia; c. menghina seseorang, agama, suku, ras, golongan, calon, dan/atau Peserta Pemilu yang lain; d. menghasut dan mengadu domba perseorangan ataupun masyarakat; e. mengganggu ketertiban umum; f. mengancam untuk melakukan kekerasan atau menganjurkan penggunaan kekerasan kepada seseorang, sekelompok anggota masyarakat, dan/atau peserta Pemilu yang lain; g. merusak dan/atau menghilangkan alat peraga kampanye Peserta Pemilu; h. menggunakan fasilitas pemerintah, tempat ibadah, dan tempat pendidikan; i. membawa atau menggunakan tanda gambar dan/atau atribut selain dari tanda gambar dan/atau atribut peserta; j. menjanjikan atau 
memberikan uang atau materi lainnya kepada peserta Kampanye pemilu. Hal yang sama ditegaskan dalam peraturan KPU. ${ }^{6}$

Proses pengawasan terhadap politik uang menjadi tugas dari Bawaslu, baik di tingkat Pusat, Propinsi maupun kabupaten, serta Panwaslu Kecamatan dan Panwaslu Kelurahan/Desa. UU Pemilu juga mengatur Sentra Penegakan Hukum Terpadu yang selanjutnya disebut Gakkumdu adalah pusat aktivitas penegakan hukum tindak pidana Pemilu yang terdiri atas unsur Bawaslu, Bawaslu Provinsi, dan/atau Bawaslu Kabupaten/Kota, Kepolisian Negara Republik Indonesia, Kepolisian Daerah dan/atau Kepolisian Resor, dan Kejaksaan Agung Republik Indonesia, Kejaksaan Tinggi, dan/atau Kejaksaan Negeri. Badan Pengawas Pemilu yang selanjutnya disebut Bawaslu adalah lembaga Penyelenggara pemilu yang mengawasi Penyelenggaraan Pemilu di seluruh wilayah Negara Kesatuan Republik Indonesia. Dalam Pasal 93 UU No. 7 Tahun 2017 tertulis: Bawaslu bertugas: a. menyusun standar tata laksana pengawasan Penyelenggaraan Pemilu untuk pengawas Pemilu di setiap tingkatan; b. melakukan pencegahan dan penindakan terhadap: (1). pelanggaran Pemilu; dan (2). sengketa proses Pemilu; c. mengawasi persiapan Penyelenggaraan Pemilu; d. mengawasi pelaksanaan tahapan Penyelenggaraan Pemilu; dan e. mencegah terjadinya praktik politik uang. Tugas Bawaslu Propinsi, Kabupaten dan Kecamatan mengikuti tugas Bawaslu di Pusat dengan kewenangan terbatas di propinsi, kabupaten dan kecamatannya masing-masing sebagaimana diatur dalam Pasal 97 dan pasal 101.

Dalam UU No. 7 Tahun 2017 juga diatur sanksi atas pelanggaran larangan kampanye dimana dalam hal terbukti pelaksana dan tim kampanye pemilu menjanjikan atau memberikan uang atau materi lainnya sebagai imbalan kepada peserta kampanye pemilu secara langsung atau tidak langsung untuk: a. tidak menggunakan hak pilihnya $b$. menggunakan hak pilihnya dengan memilih peserta pemilu dengan cara tertentu sehingga surat suaranya tidak sah; c. memilih Pasangan Calon tertentu; d. memilih Partai Politik Peserta pemilu tertentu; dan/atau e. memilih calon anggota DPD tertentu, dijatuhi sanksi administratif dan pidana. Sanksi administratif ditetapkan oleh KPU Propinsi dan KPU Kabupaten berupa a. pembatalan nama calon anggota DPR, DPD, DPRD provinsi; dan DPRD kabupaten/kota dari daftar calon tetap; atau b. pembatalan penetapan calon anggota DPR, DPD, DPRD provinsi, dan DPRD kabupaten/kota sebagai calon terpilih. ${ }^{7}$ Tentu saja, sanksi administratif diberikan setelah ada putusan pengadilan yang berkekuatan hukum tetap.

Dalam praktiknya, sanksi administratif masih menyisakan persoalan, karena hingga sekarang banyak kasus tidak dapat diputus karena persoalan pada ayat 3, pasal 286 ini: "Pelanggaran sebagaimana dimaksud pada ayat (2) merupakan pelanggaran yang terjadi secara terstruktur, sistematis, dan masif." Dalam penjelasan pasal ini ditulis: Yang dimaksud dengan pelanggaran terstruktur' adalah kecurangan yang dilakukan oleh aparat struktural, baik aparat pemerintah maupun penyelenggara pemilihan secara kolektif atau secara bersama-sama. Yang dimaksud dengan "pelanggaran sistematis' adalah pelanggaran yang direncanakan secara matang, tersusun, bahkan sangat rapi. Yang dimaksud dengan "pelanggaran masif" adalah dampak pelanggaran yang sangat luas pengaruhnya terhadap hasil pemilihan bukan hanya sebagian. Klausul terstruktur, sistematis dan masif inilah yang membuat politik uang yang dilakukan secara spontan dan sporadis terus terjadi karena justru dilindungi oleh undang-undang. Banyak politikus kotor dapat terhindar dari putusan pengadilan karena tindakan politik uang yang dilakukan tidak masuk dalam klausul

\footnotetext{
${ }^{6}$ Peraturan Komisi Pemilihan Umum Republik Indonesia Nomor 23 Tahun 2018 Tentang Kampanye Pemilihan Umum Pasal 69 dan Pasal 72.

${ }^{7}$ Pasal 285, UU No. 7 Tahun 2017 tentang Pemilihan Umum.
} 
terstruktur, sistematis, dan masif. Padahal, UU seharusnya memberi sanksi atas semua jenis politik uang karena hal tersebut justru bertentangan dengan asas bebas dan jujur.

Salah satu celah politik uang selain klausul "terstruktur, sistematis, dan masif" terdapat juga dalam penjelasan umum mengenai "materi lainnya" dimana tidak termasuk barang-barang pemberian yang merupakan atribut Kampanye Pemilu, antara lain kaus, bendera, topi, dan atribut lainnya serta biaya/uang makan dan minum peserta kampanye, biaya/uang transpor peserta kampanye, biaya/uang pengadaan bahan kampanye pada pertemuan terbatas dan/atau pertemuan tatap muka dan dialog, dan hadiah lainnya berdasarkan nilai kewajaran dan kemahalan suatu daerah yang ditetapkan dengan Peraturan KPU. Inilah celah politik uang terbesar. Karena atas dasar uang transport dan hadiah lainnya, peserta pemilu dengan terbuka dan bebas dapat memberikan uang tunai kepada pemilih.

Sesuai UU No. 7 Tahun 2017, praktik politik uang juga termasuk dalam tindak pidana pemilihan. Oleh karena itu penanganannya dilakukan mengikuti prosedur penanganan tindak pidana pemilihan yang melibatkan 2 (dua) instansi lain yaitu kejaksaan dan kepolisian. Ketiganya tergabung dalam lembaga yang dinamakan dengan Sentra Gakkumdu (Sentra Penegakan Hukum Terpadu). Lembaga ini hanya terdapat di tingkat kabupaten/kota, provinsi dan di tingkat pusat (RI). Sanksi pidana terhadap politik uang diselesaikan dalam Gakkumdu. Dengan bukti permulaan yang cukup Panwaslu Kecamatan dan Panwaslu Kelurahan/Desa dapat melaporan terjadinya politik uang kepada PPK (Panitia Pemilihan Kecamatan) dan PPS (Panitia Pemungutan Suara). PPK akan melanjutkan temuan tersebut ke KPU Kabupaten. ${ }^{8}$ Dan, selanjutnya, laporan dugaan tindak pidana Pemilu diteruskan oleh Bawaslu, Bawaslu Provinsi, Bawaslu (Kabupaten/ Kota, dan/ atau Panwaslu Kecamatan kepada Kepolisian Negara Republik Indonesia paling lama 1 x 24 (satu kali dua puluh empat) jam sejak Bawaslu, Bawaslu Provinsi, Bawaslu Kabupaten/Kota, dan/atau Panwaslu Kecamatan menyatakan bahwa perbuatan atau tindakan yang diduga merupakan tindak pidana Pemilu. Laporan dugaan Tindak Pidana Pemilu diteruskan oleh Pengawas Pemilu kepada penyidik Kepolisian Negara Republik Indonesia pada Gakkumdu. ${ }^{9}$ Gakkumdu di sini terdiri atas penyidik yang berasal dari Kepolisian Negara Republik Indonesia dan penuntut yang berasal dari Kejaksaan Agung Republik Indonesia. Penyidik dan penuntut sebagaimana dimaksud pada ayat (3) menjalankan tugas secara penuh waktu dalam penanganan tindak pidana Pemilu. ${ }^{10}$ Sesuai UU, pihak pengadilan harus memutus perkara tujuh (7) hari setelah pelimpahan berkas perkara. Dan selanjutnya, KPU, KPU Provinsi, dan KPU kabupaten/Kota wajib menindaklanjuti putusan pengadilan. Ketentuan pidananya diatur dalam UU No. 7 Tahun 2017, pasal 523.

Regulasi pemerintah di atas memang bisa untuk menjaring politik uang dalam skala besar yang dapat saja dilakukan oleh peserta dan partai politik. Namun, tidak cukup untuk mengatasi politik uang yang sangat berbahaya bagi kelangsungan demokrasi bangsa ini. Justru, banyak praktik politik uang terjadi secara spontan dan sporadis. Keprihatinan ini hanya bisa diatasi jika setiap masyarakat memiliki kesadaran "anti politik uang". Artinya, setiap masyarakat memiliki kesadaran untuk tidak melakukan, mengajak orang lain untuk menghindari praktik ini, dan melaporkan kepada pihak berwenang jika menemukan praktik politik uang ini. Dalam Peraturan Badan Pengawas Pemilihan Umum Republik Indonesia Nomor 7 Tahun 2018 Tentang Penanganan Temuan Dan Laporan Pelanggaran Pemilihan Umum, Pasal 6 disebutkan bahwa laporan dugaan pelanggaran pada setiap tahapan penyelenggaraan Pemilu dapat disampaikan oleh: a. Warga Negara Indonesia yang

\footnotetext{
${ }^{8}$ Pasal 307, 308, 309, dan 312 UU No. 7 Tahun 2017 tentang Pemilihan Umum.

${ }^{9}$ Pasal 29, Peraturan Badan Pengawas Pemilihan Umum Republik Indonesia Nomor 7 Tahun 2018.

${ }^{10}$ Pasal 486, UU No. 7 Tahun 2017 tentang Pemilihan Umum.
} 
mempunyai hak pilih; b. Peserta Pemilu; atau c. Pemantau Pemilu. Lanjut, dalam Pasal 7 ditulis: laporan Dugaan Pelanggaran Pemilu disampaikan kepada Pengawas Pemilu paling lama 7 (tujuh) hari sejak diketahui terjadinya dugaan Pelanggaran Pemilu. Peraturan ini memungkinkan setiap masyarakat untuk sadar melaporkan praktik politik uang yang terjadi di sekitarnya. Tentu saja, setiap masyarakat yang melaporkan praktik politik uang diharapkan membawa saksi dan bukti dari praktik politik uang tersebut.

\section{Politik Uang Bertentangan Dengan Moralitas Katolik}

Pada tahun 2018 ini, umat akan mengikuti Pilkada Serentak dan selanjutnya masyarakat akan memilih lagi untuk presiden dan wakil presiden, anggota legislatif DPR (Dewan Perwakilan Rakyat), DPD (Dewan Perwakilan Daerah), DPRD Propinsi dan DPRD Kabupaten pada tanggal 17 April 2019 nanti. Sesungguhnya, pemilu merupakan bagian dari upaya untuk melaksanakan demokrasi dan kedaulatan rakyat. Pemilu dilakukan agar pemerintahan yang terbentuk merepresentasikan kehendak bersama dari segenap elemen kebangsaan untuk membentuk dan melanjutkan konsepsi kenegaraan. Konsep ini, seharusnya mendorong masyarakat untuk berpartisipasi aktif dalam setiap tahapan pemilu. Termasuk dalam bentuk partisipasi masyarakat adalah menolak politik uang yang menjadi penyakit politik bangsa ini.

Berhadapan dengan politik uang ini, Gereja sendiri tentunya menolak dengan tegas politik uang. Sudah sering kita mendengar seruan moral dan pengajaran dari tokoh-tokoh Gereja mengenai berpolitik secara benar dan bertanggung jawab. Misalnya menyongsong Pilkada Serentak tahun 2018, Komisi Kerasulan Awam mengeluarkan seruan moral yang bertujuan untuk mengajak umat untuk terlibat secara aktif dalam Pilkada Serentak tersebut. ${ }^{11}$ Bagi Gereja, Politik adalah sarana untuk mewujudkan kesejahteraan bersama.

Gereja Katolik sendiri sejak lama memberi perhatian pada politik sekalipun ada perbedaan mendasar antara agama dan politik. Ajaran agama menekankan keimanan, ritual peribadatan, dan moralitas. Adapun politik menekankan aturan main yang mengarah pada perebutan dan pembagian kekuasaan dalam konteks kehidupan bernegara. Sekalipun berbeda, kedua aspek itu pada praktiknya saling memengaruhi, bahkan tak terpisahkan. Dalam Dekrit Gaudium Et Spes, Gereja dalam Dunia Modern art. 76 tertulis:

berdasarkan tugas maupun wewenangnya Gereja sama sekali tidak dapat dicampuradukkan dengan negara, dan tidak terikat pada sistem politik mana pun juga. Sekaligus Gereja itu menjadi tanda dan perlindungan transendensi pribadi manusia. Di bidang masing-masing negara dan Gereja bersifat otonom, tidak saling bergantung. Tetapi keduanya, kendati atas dasar yang berbeda, melayani panggilan pribadi dan sosial orang-orang yang sama. ${ }^{12}$

Bagi Gereja, setiap pemerintahan adalah partner dalam pelayanan umat manusia menuju kesejahteraan umum. Keduanya menjalin kerja sama yang sehat, dengan mengindahkan situasi setempat dan semasa. Gereja, yang bertumpu pada cinta kasih Sang Penebus, menyumbangkan bantuannya, supaya di dalam kawasan bangsa sendiri dan antara bangsabangsa makin meluaslah keadilan dan cinta kasih. Gereja juga menghormati dan mengembangkan kebebasan serta tanggung jawab politik para warga negara.

Gereja memandang politik dalam hubungannya dengan "kebaikan Umum". Dalam Katekismus Gereja art. 407 tertulis: "kebaikan umum ialah semua kondisi kehidupan sosial

11 Komisi Kerasulan Awam, Seruan Moral Komisi Kerawam KWI Dalam Pilkada Serentak 2018 (Jakarta: KWI, 2018), hal 2. hal. 614 .

${ }^{12}$ R. Hardawiryana, Dokumen Konsili Vatikan II (Jakarta: Dokumentasi dan Penerangan KWI, 1992), 
yang memungkinkan orang-orang sebagai kelompok atau individu mencapai kesempurnaan (kebahagiaan) mereka sendiri". ${ }^{13}$ Dan, realisasi paling lengkap dari kebaikan umum ini dapat ditemukan dalam komunitas politik yang membela dan mengembangkan kebaikan warga mereka dan kelompok-kelompok yang ada dalam masyarakat tanpa melupakan kebaikan universal seluruh keluarga manusia. ${ }^{14}$ Dengan demikian, Gereja memandang positif setiap usaha dan kerja keras dari kelompok-kelompok sosial/politik maupun partai-partai politik yang melalui visi misinya mendengarkan aspirasi rakyat dan melanjutkannya dalam ruang legislatif untuk dilaksanakan pihak eksekutif demi kebaikan semua orang. Untuk itu, Gereja selalu mendorong umat untuk terlibat aktif dalam proses berpolitik. "Semua orang menurut tempat dan peranan yang mereka punyai dapat berpartisipasi dalam mengusahakan kebaikan umum, yakni dengan menghormati hukum yang adil dan melaksanakan tugas di tempat dia mempunyai tanggung jawab... Para warga negara juga wajib berpartisipasi aktif dalam kehidupan publik sejauh itu mungkin". ${ }^{15}$

Dalam hal ini, Gereja tentu berharap dari kaum awam katolik, untuk benar-benar menjadi garam dan terang dunia. Kaum awam, berbeda dari para imam, adalah bahwa kaum awam hidup di tengah-tengah masyarakat dan mengurus perkara-perkara duniawi. Kaum awam diharapkan tidak saja untuk menjadi pewarta injil, tetapi juga merasuki dan menyempurnakan tata dunia dengan semangat injil yang diwartakan. ${ }^{16}$ Ketika seorang awam terjun dalam dunia politik, ia benar-benar menjadi pejuang kebaikan bersama. Politik bukanlah seni tipu menipu, tetapi justru sebaliknya, yaitu seni mencari kemungkinankemungkinan alternatif untuk memperjuangkan kepentingan umum dan seni menjinakkan nafsu akan kekuasaan. ${ }^{17}$ Para awam katolik yang menduduki posisi kekuasaan tentunya mempunyai tanggung jawab lebih bagi keadilan sosial, karena masa depan banyak orang ada di tangan keputusan mereka. Dan bagi:

mereka yang menjadi subjek otoritas harus memandang mereka yang mempunyai otoritas sebagai representasi Allah dan membuka kerja sama dengan mereka supaya kehidupan publik dan sosial berfungsi. Kerja sama ini meliputi cinta dan pelayanan untuk tanah air, hak dan kewajiban untuk menggunakan hak pilih, kewajiban membayar pajak, membela negara, dan hak untuk memberikan kritik yang membangun. ${ }^{18}$

Dengan demikian, politik uang pastilah ditolak dan dilarang oleh Gereja. Hal ini melawan prinsip moralitas katolik yang menjunjung tinggi martabat pribadi manusia, kebenaran dan kebaikan umum. Politik uang mencederai martabat manusia sebagai yang diciptakan menurut citra Allah, maka setiap hidup manusia adalah suci dan tidak pernah boleh dilakukan sebagai sarana. ${ }^{19}$ Ini berarti setiap bidang kehidupan manusia baik itu ekonomi, sosial, budaya, apalagi politik harus dinilai berdasarkan kriteria, apakah bidang itu melindungi atau justru menghancurkan martabat manusia. Politik uang merongrong martabat manusia karena justru kebebasan setiap orang untuk memilih digadai dengan sejumlah uang. Praktik ini justru sangat merendahkan martabat manusia.

${ }^{13}$ Harry Susanto (Penterj.), Kompendium Katekismus Gereja Katolik (Yogyakarta: Kanisius, 2013), hal 138.

${ }^{14}$ Ibid.

15 Ibid.

${ }^{16}$ Sekretariat KWI, Kitab Hukum Kanonik (Jakarta:Obor, 2004), hal. 84.

${ }^{17}$ Jacobus Tarigan, Religiositas Agama dan Gereja Katolik (Yogyakarta:PT Kanisius, 2007), hal. 119.

${ }^{18}$ Harry Susanto, Op. Cit., hal 157.

19 Agus M. Hardjana, (pentrj.) Thomas P. Rausch, Katolisisme (Teologi bagi kaum awam) (Yogyakarta: PT Kanisius, 2001), hal, 258. 
Semua umat Katolik baik sebagai pemilih, kandidat, penyelenggara pemilu, diajak untuk menolak politik uang dengan segala dimensinya. Hanya dengan itu, umat Katolik dapat mewujudkan kehidupan berbangsa dan bergereja yang benar dan mewujudkan kebaikan bersama. Semua umat Katolik diajak untuk mengabdi kepada negaranya dengan jujur dan setia tanpa melalui proses yang curang dan tidak adil. Politik uang justru melukai moralitas umat Katolik yang sedang berjuang untuk kebaikan bersama. Dalam dekrit Kerasulan awam Apostolicam Actuositatem, art. 14 tertulis:

Dalam berbakti kepada bangsa dan dalam menunaikan tugas-tugas kewarganegaraan dengan setia, Umat Katolik hendaknya menyadari kewajibannya untuk memajukan kesehjateraan umum yang sejati... Hendaknya orang-orang Katolik, yang mahir di bidang politik, dan sebagaimana wajarnya berdiri teguh dalam iman serta ajaran Kristiani, jangan menolak untuk menjalankan urusan-urusan umum. Hendaknya umat Katolik berusaha bekerja sama dengan semua orang yang beritikad baik, untuk memajukan apa pun yang benar, apa pun yang adil, apa pun yang suci, apa pun yang manis (Flp 4:8).

\section{Kesimpulan}

Akhirnya, menolak politik uang adalah suatu keharusan bagi umat beriman yang $100 \%$ warga gereja dan sekaligus $100 \%$ warga Indonesia. Demokrasi yang dijunjung di negara ini untuk melindungi dan memajukan kesejahteraan masyarakat sedang digoncang oleh penyakit politik uang. Kesadaran ini perlu ada pada setiap pribadi dan diteruskan pada orang lain, agar praktik ini tidak semakin merajalela. UU No. 7 Tahun 2017 menjadi payung hukum, agar setiap masyarakat tidak takut untuk melawan politik uang. Karena, untuk melawan politik uang tidak cukup dengan himbauan dan nasihat-nasihat, tetapi sanksi hukum yang tegas. Imbauan etis juga tidak ada gunanya karena ketumpulan dan kebusukan politik akibat politik uang sudah demikian jauh. Yang dibutuhkan adalah kesadaran masyarakat untuk menolak ketika ditawari uang, dan tidak memilih para politisi yang mengadai suara seseorang dengan sejumlah uang. Rantai politik uang dapat diatasi, dimulai dari pribadi-pribadi beriman yang memegang teguh pada kejujuran dan kebebasan yang bertanggung jawab.

Melawan "politik kotor", setiap umat beriman dipanggil untuk mengusahakan kekudusan surga lewat kerasulan di bidang politik. Pemilu tanpa politik uang, mungkin sesuatu yang lucu dan aneh bagi orang-orang yang haus kekuasaan, tapi tidak aneh dan lucu bagi orang yang memperjuangkan keadilan. Pemilu tanpa politik uang adalah sesuatu yang tidak mungkin bagi mereka yang sudah kehilangan martabat karena uang, tapi mungkin bagi mereka yang melihat keindahan kebebasan dan kejujuran untuk kebaikan bersama.

\section{Daftar Kepustakaan}

\section{Dokumen Gereja}

Hardawiryana, R. 1992. Dokumen Konsili Vatikan II. Jakarta: Dokumentasi dan Penerangan KWI.

Sekretariat KWI. 2004. Kitab Hukum Kanonik, Jakarta:Obor.

Susanto, Harry (Penterj.). Konferensi Waligereja Indonesia. 2010. Kompendium Katekismus Gereja Katolik. Yogyakarta: Kanisius.

\section{Undang-Undang dan Peraturan}

Undang-Undang No. 7 Tahun 2017 tentang Pemilihan Umum 
Peraturan Komisi Pemilihan Umum Republik Indonesia Nomor 23 Tahun 2018 Tentang Kampanye Pemilihan Umum

Peraturan Badan Pengawas Pemilihan Umum Republik Indonesia Nomor 7 Tahun 2018

\section{Buku-buku}

Chang, William. 2001. Pengantar Teologi Moral. Yogyakarta: Kanisius.

Go Piet dkk. 2004. Etos dan Moralitas Politik. Yogyakarta:Kanisius.

Hadiwardoyo, AL. Purwa. 2017. Ringkasan Ajaran Gereja tentang Imam, Awam, dan Religius. Yogyakarta: PT Kanisius.

Hardjana, Agus M (pentrj.) Rausch, Thomas P. 2001. Katolisisme (Teologi bagi kaum awam). Yogyakarta: PT Kanisius.

Indra Ismawan, 1999. Money Politics Pengaruh Uang dalam Politik. Yogyakarta: Media Presindo.

Kholiludin, Tedi. 2011. Kuasa Negara Atas Agama. Yogyakarta: RaSAIL.

Komisi Kerasulan Awam. 2018. Seruan Moral Komisi Kerawam KWI Dalam Pilkada Serentak 2018. Jakarta: KWI.

Tarigan, Jacobus. 2007. Religiositas Agama dan Gereja Katolik. Yogyakarta:PT Kanisius.

Surbakti Ramlan. 1992. Memahami Ilmu Politik, Jakarta, Gramedia Pustaka Utama.

Suseno, F. Magnis. 2006. Etika Abad Kedua Puluh. Yogyakarta:Kanisius.

\section{Jurnal dan Internet}

Ananingsih, Sri Wahyu. Tantangan Dalam Penanganan Dugaan Praktik Politik Uang Pada Pilkada Serentak 2017, Jurnal Masalah-masalah Hukum, Vol 45, No 1 (2016). Dapat diunduh dalam ejournal.undip.ac.id/index.php/mmh/article/view/13671.

Fitriyah, Fenomena Politik Uang dalam Pilkada, Politika Jurnal Ilmu Politik. Dapat diunduh dalam. https://ejournal.undip.ac.id/index.php/politika/article/view/4824/4373.

Https://ekonomi.kompas.com/read/2018/08/01/064607526/ingin-jadi-caleg-berapa-miliardana-dibutuhkan, diakses tanggal 16 Nopember 2018.

Https://ditpolkom.bappenas.go.id/.../007. pdf,diakses tanggal 11 Nopember 2018. 